\title{
Physiological responses of marine and brackish water bacterial assemblages in a tidal estuary (Ria de Aveiro, Portugal)
}

\author{
M. A. Almeida*, M. A. Cunha, F. Alcântara \\ Departamento de Biologia, Universidade de Aveiro, Campus Universitário de Santiago, 3810-193 Aveiro, Portugal
}

\begin{abstract}
The reactivity of spatially distinct bacterial communities within an estuarine gradient to contrasting water properties was evaluated in the field and experimentally tested in diffusion chambers. In field conditions, it was observed that total and active bacterial numbers were, on average, 3 times higher in brackish water than in marine water. The fraction of active bacteria was, however, similar in both zones (26.6\% on average). Total leucine incorporation, as a measure of biomass productivity, was 3.5 times higher in the brackish water zone following the increase in bacterial population size. Productivity seemed also to depend on the level of activity of individual cells since specific leucine incorporation per active cell was $19 \%$ higher in the brackish water zone. Experimental assays in diffusion chambers showed that when the marine bacterial community was exposed for $6 \mathrm{~h}$ to brackish water, the fraction of active bacteria and leucine incorporation increased (20 to $60 \%$ and 50 to $220 \%$, respectively). The opposite was observed when the brackish water community was exposed to marine water $(20 \%$ decrease in the fraction of active bacteria and 50 to $80 \%$ decrease in leucine incorporation). The positive response of marine bacteria to the brackish water conditions was higher when the salinity of the brackish water was artificially increased to $34 \mathrm{psu}$. Brackish water bacteria, however, responded negatively to this increase in salinity. When the marine community was exposed for only $2 \mathrm{~h}$ to brackish water, it promptly showed increased activity. The immediate transfer of this community to marine water for an extra $4 \mathrm{~h}$ period induced a return to the initial low activity level. In contrast, the negative response of the brackish water community after $2 \mathrm{~h}$ of exposure to marine water was irreversible when transferred back to brackish water. Bacteria remained at a low activity level for the extra $4 \mathrm{~h}$. The high bacterial abundance and production in mid-estuary and the similar patterns of variation of total and active bacteria throughout the system seemed to indicate conservative transport of a euryhaline bacterial community from its main source in the mid-estuary. However, the experimental assays with diffusion chambers invalidated this hypothesis. They suggest the presence of 2 communities: a nutrient-limited marine zone community that grows optimally at high salinity and a nutrient-replete brackish water community requiring salinities below 25 psu.
\end{abstract}

KEY WORDS: Active bacteria - Leucine incorporation · Bacterial stimulation · Estuary

Resale or republication not permitted without written consent of the publisher

\section{INTRODUCTION}

Bacterioplankton communities in estuarine systems are frequently exposed to varying environmental conditions. The mixing of seawater and freshwater, the

*E-mail: aalmeida@bio.ua.pt different residence time, the transportation of materials from diverse sources, including salt marshes, mudflats, rivers and bottom sediments, and different climatic conditions may induce different patterns of bacterial abundance and activity in different estuaries. Estuarine gradients of bacterial abundance are generally characterised by a steady increase in density (factors up to 3 ) from the outer to the upper estuary 
(Palumbo \& Fergunson 1978, Goosen et al. 1997) or to the mid-estuary (Wright \& Coffin 1983, Bordalo et al. 1998, Cunha et al. 2000). Although the metabolically active cells in these populations correspond generally to a small fraction, rarely reaching $50 \%$ (Rodriguez et al. 1992, Button et al. 1993, del Giorgio \& Scarborough 1995, Zweifel \& Hagstrom 1995, Ullrich et al. 1996, Choi et al. 1999, Sherr et al. 1999), the shifts in water characteristics have been reported to induce stronger responses in the size of the fraction of active bacteria than in the total bacterial number (del Giorgio \& Scarborough 1995). The relative size of this fraction is minimal in oligotrophic ocean water $(<5 \%)$ and increases towards the estuaries up to $50 \%$ (Rodriguez et al. 1992, Button et al. 1993, Gasol et al. 1995, del Giorgio \& Scarborough 1995). The reasons underlying this variation are not well understood. Substrate availability has been extensively studied as a potentially important factor controlling cell activity. A number of studies showed positive correlation between the number of active bacteria and the concentration of inorganic nutrients and of dissolved organic carbon in highly productive lakes and estuaries (del Giorgio \& Scarborough 1995). The systematic differences in the percentage of active cells in systems with comparable trophic conditions suggest that other factors combine to control bacterial activity (del Giorgio \& Scarborough 1995). Temperature (Quinn 1984, Tabor \& Neihof 1984, Wright \& Coffin 1984, Shiah \& Ducklow 1994), salinity (Riegsbee et al. 1996), viral infection (Proctor \& Fuhrman 1990) and bacterial predation (Gonzalez et al. 1990, Sherr et al. 1992, Bird \& Kalf 1993, Cole \& Caraco 1993) may interact and produce different final results.

Bacterial responses to changing water properties are generally higher in terms of activity rates than in terms of abundance (del Giorgio et al. 1996). Leucine incorporation, different enzymatic activities and glucose turnover, although maximal in the mid-estuary, may show, however, different environmental reactivities (Cunha et al. 2000). These differences in metabolic properties along the estuarine gradients may be related to the spatial distribution of distinct bacterial communities. In fact, Bidle \& Fletcher (1995) have already found, in Chesapeake Bay, genetic differences in free-living bacteria populations from the upper and mid- bay regions. Murray et al. (1996) analysed the phylogenetic diversity of bacterial assemblages in 2 California estuaries and concluded that bacterial similarity in adjacent stations was greater than in distant stations. These differences in genetic similarity may, according to the authors, be interpreted to result from the mixing of different communities or to the influence of the organic matter gradient in the physiology of the same microbial assemblage.
Previous studies on the dynamics of bacterioplankton in the lagunar system of Ria de Aveiro, Portugal, found a curvilinear profile of bacterial abundance and bacterial activities with peaks at the 20 to 30 psu section of the estuary (Cunha et al. 2000, Almeida et al. in press). Nutrients, organic matter and phytoplankton biomass concentrations were maximal in the mid- to upper estuary (Cunha et al. 1999, 2000, in press). In this study we attempted to distinguish 2 hypotheses in experimental conditions: the patterned gradient of bacterial activity results either from flexible physiological responses of a single bacterial community to a changing environment or from different reactivities of bacterial communities with distinct activity profiles.

\section{MATERIALS AND METHODS}

Study site. Ria de Aveiro (Fig. 1) is a tidal lagoon on the western coast of Portugal, which is connected to the Atlantic Ocean by a narrow opening. The lagoon covers an area of 66 to $83 \mathrm{~km}^{2}$ at low (LT) and high tide (HT), respectively (Silva 1994). It exchanges with the sea $89 \times 10^{6} \mathrm{~m}^{3}$ of water over tidal amplitudes ranging from 1 to $3 \mathrm{~m}$ (Silva 1994). Several rivers carry fresh water into the lagoon with an average water input of $1.8 \times 10^{6} \mathrm{~m}^{3}$ during a tidal cycle (Barrosa 1985). The Ria has a complex topography, with different channels spreading from the mouth towards the different streams forming, in fact, a multi-estuarine ecosystem. Secondary branches originate from the 3 main channels forming a tight network of smaller channels, islands and mudflats. For this study, 2 sampling stations were selected to represent contrasting water characteristics: Stn N1 in Canal de Navegação, representing the marine zone, and Stn I6 in Canal de Ílhavo, representing the brackish water zone.

Sampling. The marine zone of the Ria was studied during 6 different tidal cycles (1 and 3 June 1996, 28 and 30 August 1996, 2 and 10 September 1997), 5 of them in spring tide and 1 in neap tide. The brackish water zone was sampled during 4 tidal cycles (29 April and 5, 22 and 30 May 1997), 2 in spring tide and 2 in neap tide. Samples were collected at surface $(0.2 \mathrm{~m}$ from the surface) and deep water $(0.5 \mathrm{~m}$ above the sediment floor) at HT and LT and at intervals of $2 \mathrm{~h}$ (HT$2 h, H T+2 h, L T-2 h, L T+2 h)$. Water samples were transported and processed within 2 to $3 \mathrm{~h}$ after collection.

Samples for experimental assays were collected at the same 2 zones. For a better contrast of the environmental conditions at the 2 zones, Stn N1 was sampled at flood tide, $2 \mathrm{~h}$ before HT, and Stn I6 at ebb tide, $2 \mathrm{~h}$ before LT. Water samples collected during the flood tide in the marine zone represented marine environmental conditions and the corresponding bacterial 
community. Samples collected during ebb tide at Stn I6 represented the characteristics and the bacterial community of the brackish water zone of the estuary. For assays in diffusion chambers, surface water was sampled in February and June 1998 and in November 1999. For studying the response of bacteria to the amendment of nutrient several surface samples were collected at the 2 stations from January 1998 to November 1999.

Physical and chemical characteristics. Temperature and salinity were read in a conductivity meter (Model LF 196, WTW-Wissenschaftlich Technische Werkstätten, Weilheim, Germany). Dissolved oxygen concentration, expressed as percentage of saturation, was determined with an oxygen meter (Model OXI 96, WTW) equipped with a stirrer (Model BR 190, WTW). The concentration of suspended solids was determined after filtration of triplicate $0.5 \mathrm{l}$ water aliquots through pre-weighted and pre-combusted Whatman GF/C filters. The filters were dried at $60^{\circ} \mathrm{C}$ for $24 \mathrm{~h}$ and suspended solids (seston) were calculated as the increase in dry weight. The organic matter fraction in the seston was determined as the loss of weight after $4 \mathrm{~h}$ combustion at $525^{\circ} \mathrm{C}$ (Parsons et al. 1989).

Total bacterial number. Bacterial cells were counted by epifluorescence microscopy with a Leitz Laborlux K (Leitz Meßtechnik, Wetzlar, Germany) microscope equipped with a I $2 / 3$ filter for blue light. The samples were fixed with $2 \%$ formaldehyde (final concentration), filtered through black polycarbonate membranes of $0.2 \mu \mathrm{m}$ (Poretics, Livermore, CA, USA) and stained with $0.03 \%$ acridine orange (Hobbie et al. 1977). At least 200 cells or 20 microscope fields were counted in each of 3 replicate preparations.

Active bacterial number. Microautoradiography: The number of active bacteria was determined by microautoradiography (Carman 1993) after amendment with a $30 \mathrm{nM}{ }^{3} \mathrm{H}$-leucine solution (Amersham, Little Chalfont, Buckinghamshire, $\mathrm{UK}_{\text {; }}$ specific activity of 58 to $92 \mathrm{Ci} \mathrm{mmol}^{-1}$ ). After $5 \mathrm{~h}$ incubation at in situ temperature, triplicate sub-samples $(2$ to $3 \mathrm{ml}$ ) of each $10 \mathrm{ml}$ sample were filtered through black polycarbonate membranes. The filters were placed face down on slides coated with the autoradiographic emulsion NTB-2 (Kodak, Rochester, NY, USA). The exposure, in total darkness and at $4^{\circ} \mathrm{C}$, was carried out for $7 \mathrm{~d}$. The slides were developed with Kodak Detkol (1:1 dilution in ultrapure water) and fixed in Kodak fixer. The developed autoradiograms were stained with acridine orange solution $(0.04 \%)$ and hydrated in citrate buffer $(0.004 \mathrm{M})$. Microautoradiographs were examined using a combination of epifluorescence (as above) and bright-field illumination (in a Leitz Laborlux microscope). Cells were counted as active if they were associated with 3 or more silver grains.
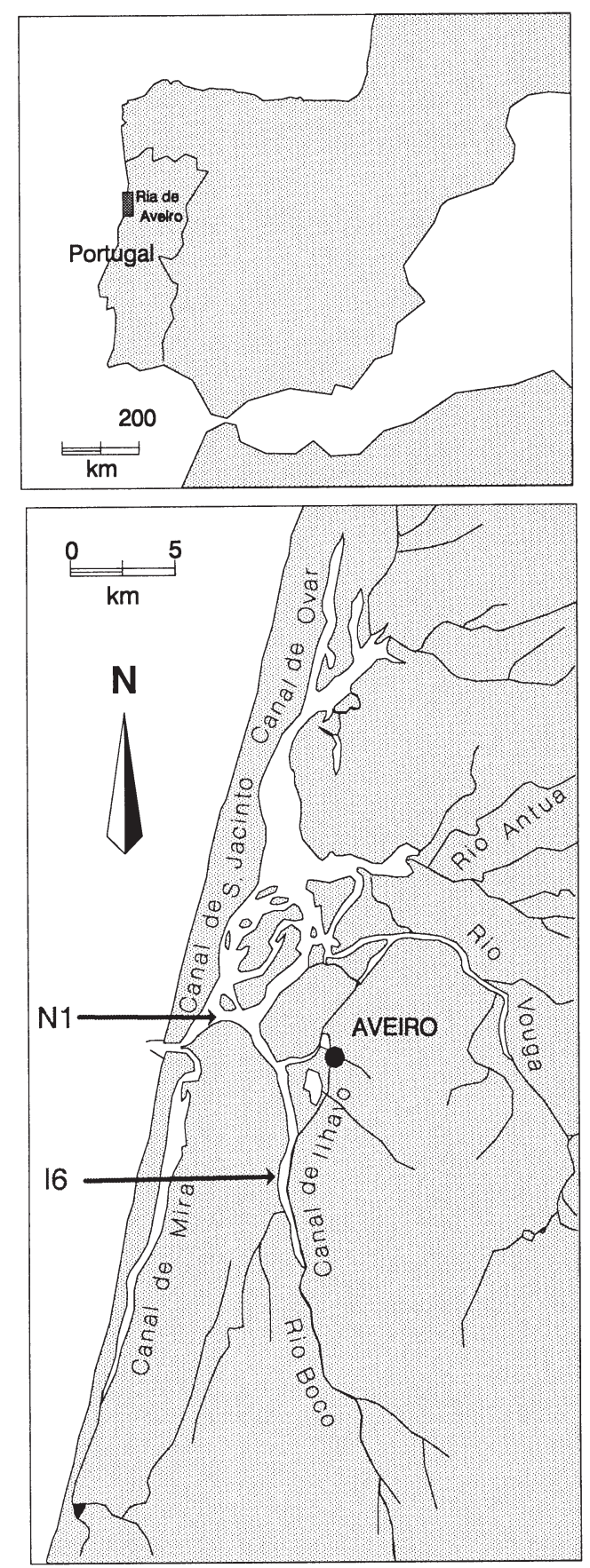

Fig. 1. Ria de Aveiro with sampling stations indicated by the arrows. Stn N1 in Canal de Navegação, representing the marine zone, and Stn I6, in Canal de Ílhavo, representing the brackish water zone

CTC reduction. Five millilitre triplicate water subsamples were placed in sterile plastic tubes and supplemented with freshly prepared 5-cyano-2,3-ditolyltetrazolium chloride (CTC) solution to a final concentration of $5 \mathrm{mM}$ (Ullrich et al. 1996). A fixed control was prepared by first adding filtered formaldehyde 
( $2 \%$ final concentration) to an otherwise similarly prepared water sample, which, after $30 \mathrm{~min}$, was further supplied with the CTC solution. Controls and test samples were incubated in the dark for $4 \mathrm{~h}$ at room temperature with slow agitation $(100 \mathrm{rpm})$. Samples were filtered through $0.2 \mu \mathrm{m}$ black polycarbonate membranes (Poretics) and observed for red fluorescence. At least 200 CTC positive cells, or 20 microscope fields, were enumerated in each of the 3 replicate samples.

Leucine incorporation. Leucine incorporation was determined in $10 \mathrm{ml}$ triplicate sub-samples plus a control that was fixed by the addition of formaldehyde ( $2 \%$ final concentration). The samples were incubated at a saturating concentration $(30 \mathrm{nM})$ of ${ }^{3} \mathrm{H}$-leucine (Amersham; specific activity of 58 to $92 \mathrm{Ci} \mathrm{mmol}^{-1}$ ) for $1 \mathrm{~h}$ at in situ temperature. Sub-samples were fixed in $2 \%$ formaldehyde. Protein was precipitated through the addition of $1 \mathrm{ml}$ of $20 \%$ ice-cold TCA, followed by incubation for $15 \mathrm{~min}$ in ice. Sub-samples were filtered through $0.2 \mu \mathrm{m}$ polycarbonate membranes (Poretics), and rinsed with $2 \mathrm{ml}$ of $5 \%$ ice-cold TCA and $5 \mathrm{ml}$ of $90 \%$ ice-cold ethanol (Bligh et al. 1995). After $3 \mathrm{~d}$ of being in scintillation cocktail (Universol) the radioactivity was read in a liquid scintillation counter (LS 6000 IC, Beckman, Fullerton, CA, USA). Leucine incorporation was calculated using a ratio of cellular carbon to protein of 0.86 and a fraction of leucine in protein of 0.073 (Simon \& Azam 1989). Cellspecific leucine incorporation was calculated as the quotient between leucine incorporation and the total bacterial number, whereas leucine incorporation per active cell was the ratio between leucine incorporation and the active bacterial number.

Bacterial activity in diffusion chambers assays. These assays were devised to measure rapid (up to $6 \mathrm{~h}$ ) responses of the bacterial community of a tidal estuarine environment to the conditions prevailing in different phases of the tidal cycles. The idea behind this was to expose the same population to changing environmental conditions. Two experimental incubation systems were prepared, each consisting of a stirred, temperature controlled water bath filled with $15 \mathrm{l}$ of water, either from Stn N1 (representing the marine zone) or from Stn I6 (representing the brackish water zone). Diffusion chambers with a capacity $170 \mathrm{ml}$ were prepared as described by Pereira \& Alcântara (1993). Two $12.5 \mathrm{~cm}$ diameter, $0.2 \mu \mathrm{m}$ pore size polycarbonate membranes formed the sides of each chamber, and allowed ample percolation of water and dissolved substances. One set of 7 diffusion chambers was filled with water from the marine zone and the other set with water from the brackish zone. Four chambers from each set were incubated in the bath filled with the same type of water ( 1 blank and 3 controls) and the other 3 in the contrasting bath (test chambers). The closed chambers were incubated completely immersed in the water bath at $20^{\circ} \mathrm{C}$ for $6 \mathrm{~h}$, corresponding approximately to the duration of half a tidal cycle. Samples were taken after 2, 4 and $6 \mathrm{~h}$ of incubation without removing the chambers from the bath. Each time a volume of $40 \mathrm{ml}$ of water was collected through an opening at the top of the chamber. Dilution due to permeation after sampling (entrance of water due to the reduction of pressure inside the chambers) was taken into account and corrected using the blank chambers, which were also sampled after 2, 4 and $6 \mathrm{~h}$. In the blank chambers the remaining volume of water was always measured and again inserted into the chamber. At the end of the exposure period, the volume of water inside the test, control and blank chambers was also measured. The initial characteristics of the marine and brackish water samples were determined immediately after field sampling.

In June 1998, to test the effects of exposure reversion, an extra chamber of each set was incubated in the contrasting water for the first $2 \mathrm{~h}$, sampled and transferred to the 'natural' environment (bath with similar water) before being refilled and incubated for an additional $4 \mathrm{~h}$. Further samples were taken after 4 and $6 \mathrm{~h}$ of incubation in the now reversed conditions.

In November 1999, to evaluate the effects of increased salinity on bacteria, samples from Stns N1 and I6 were exposed to natural brackish water conditions (salinity $18 \mathrm{psu}$ ) and to the same water to which $\mathrm{NaCl}$ was added to get a salinity of $34 \mathrm{psu}$, which was similar to that of the marine zone and processed as above.

These samples were analysed for total bacterial number, active bacterial number and leucine incorporation. The active bacterial numbers were determined in February and June 1998 by the microautoradiography method, while in November 1999 the CTC reduction method was used. The values obtained for total bacterial number, active bacterial number and leucine incorporation were multiplied by the inverse of the factor of dilution determined in the blank chamber.

Bacterial activity after supplement amendment. Surface water samples were complemented with different combinations of inorganic and organic substrates to induce recovery from occasional dormancy in the bacterial communities. Marine and brackish water samples were separately enriched with different substrates as described in Table 1.

To avoid significant dilution of the samples, 10 to 100 times concentrated substrate solutions were used. Samples for active cell counting were taken $10 \mathrm{~min}$ after substrate addition, except in November 1999, when the pre-stimulation period was extended to 1,2 or $3 \mathrm{~h}$. Active bacterial numbers were determined 
using the CTC technique (see above). It is assumed that during the short incubation period the total number of bacterial cells did not increase significantly. To avoid interference of CTC fluorescence in total bacterial counts, parallel sub-samples were incubated, after the supplement addition but without CTC, for determination of total counts.

\section{RESULTS}

\section{Physical, chemical and biological properties of marine and estuarine water}

During the tidal cycle, the salinity varied from 23.7 to $36.1 \mathrm{psu}$ (average $34.4 \mathrm{psu}$ ) in the marine zone and from 11.4 to $33.7 \mathrm{psu}$ (average $26.0 \mathrm{psu}$ ) in the brackish water zone. The average water temperature was $16.8^{\circ} \mathrm{C}$ (range 15.3 to 20.6 ) in the marine zone and $20.2^{\circ} \mathrm{C}$ (range 17.0 to 23.5 ) in the brackish water zone. Oxygen concentration was usually below saturation in both zones. The mean value was $76.7 \%$ in the marine zone and $69.8 \%$ in the brackish water zone. Particulate organic matter varied from 6.0 to $31.0 \mathrm{mg} \mathrm{l}^{-1}$ (average 14.4 $\mathrm{mg} \mathrm{l}^{-1}$ ) in the marine zone and from 6.0 to $17.0 \mathrm{mg} \mathrm{l}^{-1}$ (average $11.0 \mathrm{mg} \mathrm{l}^{-1}$ ) in the brackish water zone. No stratification could be assigned to any of the physical and chemical variables studied in either of the 2 lagoon zones.

Total bacterial number varied in different phases of the tidal cycles from $0.2 \times 10^{9}$ to $8.5 \times 10^{9}$ cells $\mathrm{l}^{-1}$ (Table 2). The active bacteria number (determined by microautoradiography) varied from $0.9 \times 10^{8}$ to $31.0 \times$

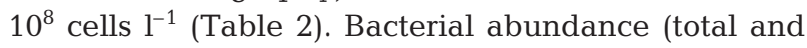
active) was, on average, 3 times higher in the brackish water zone than in the marine zone. In both zones the highest values of total and active bacteria were observed near LT (Fig. 2). Although total and active bacterial densities were frequently higher at the surface in the marine zone, the values were not significantly different from those observed near the bottom. In the shallower brackish water zone, the values were rather similar throughout the water column. The average fraction of active bacteria was similar in both zones $(26.6 \%)$, down the water column and over the tidal cycle (Table 2).

Leucine incorporation varied from 0.05 to $14.2 \mu \mathrm{g} \mathrm{C}$ $\mathrm{l}^{-1} \mathrm{~h}^{-1}$ (Table 2) and the average value was 3.5 times larger in the brackish water zone. The values were higher near LT mainly in the marine zone. In the marine zone, leucine incorporation was higher at surface water, reaching values of up to 8.5 times higher than that in near-bottom water. In the brackish water zone the leucine incorporation did not vary along the water column (Fig. 3). Leucine incorporation per cell (from total bacterial number) was similar in both zones ( $0.7 \mathrm{fg} \mathrm{C} \mathrm{Cell}^{-1} \mathrm{~h}^{-1}$, on average) and ranged from 0.05 to $2.6 \mathrm{fg} \mathrm{C} \mathrm{Cell}^{-1} \mathrm{~h}^{-1}$ (Table 2). However, leucine incorporation per active cell was, on average, $19 \%$ higher in the brackish water zone than in the marine zone (range from 0.2 to $9.6 \mathrm{fg} \mathrm{C}$ active cell ${ }^{-1} \mathrm{~h}^{-1}$ ). In the marine zone leucine incorporation per cell and per active cell were also higher near LT, and the maximum values were observed at the surface. In the brackish water zone, these parameters were similar at LT and HT, and were constant down the water column (Fig. 3). 
Table 2. Bacterial abundance and production in the marine and brackish water zones of the Ria de Aveiro. Determinations at surface $(0.2 \mathrm{~m}$ below surface) and deep water $(0.5 \mathrm{~m}$ above floor) at high tide and low tide and at intervals of $2 \mathrm{~h}$ as indicated. The value shown for each tidal phase was calculated as the average of 6 (marine zone) and 4 (brackish water zone) determinations in different sampling dates of the warm season. TBN: total bacteria number; ABN: active bacteria number determined by microautoradiography; \% AB: proportion of active bacteria; LI: leucine incorporation; $\mathrm{LI}_{\text {cell }}$ : specific LI per cell; $\mathrm{LI}_{\text {act cell }}$ : specific LI per active cell; S: surface water; D: deep water. Ranges of values are shown in parentheses

\begin{tabular}{|c|c|c|c|c|c|c|}
\hline Sample & $\begin{array}{c}\text { TBN } \\
\left(\times 10^{9}{\left.\text { cells } 1^{-1}\right)}^{-1}\right.\end{array}$ & $\begin{array}{c}\text { ABN } \\
\left(\times 10^{8}{\left.\text { cells } 1^{-1}\right)}^{-1}\right.\end{array}$ & $\% A B$ & $\begin{array}{c}\mathrm{LI} \\
\left(\mu \mathrm{g} \mathrm{Cl^{-1 }} \mathrm{h}^{-1}\right)\end{array}$ & \multicolumn{2}{|c|}{$\begin{array}{l}\mathrm{LI}_{\text {cell }} \mathrm{LI}_{\text {act cell }} \\
\quad\left(\mathrm{fg} \mathrm{cell}^{-1} \mathrm{~h}^{-1}\right)\end{array}$} \\
\hline \multicolumn{7}{|c|}{ Marine zone } \\
\hline $\mathrm{S}$ & $\begin{array}{c}2.3 \\
(0.2-8.1)\end{array}$ & $\begin{array}{c}5.1 \\
(1.0-13.0)\end{array}$ & $\begin{array}{c}27.7 \\
(10.0-53.0)\end{array}$ & $\begin{array}{c}1.6 \\
(0.3-4.5)\end{array}$ & $\begin{array}{c}0.9 \\
(0.2-2.3)\end{array}$ & $\begin{array}{c}3.1 \\
(0.6-7.2)\end{array}$ \\
\hline $\mathrm{D}$ & $\begin{array}{c}1.8 \\
(0.2-5.9)\end{array}$ & $\begin{array}{c}4.6 \\
(1.4-17.0)\end{array}$ & $\begin{array}{c}28.6 \\
(5.9-55.0)\end{array}$ & $\begin{array}{c}0.6 \\
(0.05-2.1)\end{array}$ & $\begin{array}{c}0.5 \\
(0.05-2.6)\end{array}$ & $\begin{array}{c}1.5 \\
(0.2--6.1)\end{array}$ \\
\hline $\mathrm{S}+\mathrm{D}$ & $\begin{array}{c}2.0 \\
(0.2-8.1)\end{array}$ & $\begin{array}{c}4.9 \\
(1.0-17.0)\end{array}$ & $\begin{array}{c}27.3 \\
(5.9-55.0)\end{array}$ & $\begin{array}{c}1.1 \\
(0.05-4.5)\end{array}$ & $\begin{array}{c}0.7 \\
(0.05-2.6)\end{array}$ & $\begin{array}{c}2.2 \\
(0.2-7.2)\end{array}$ \\
\hline \multicolumn{7}{|c|}{ Brackish water zone } \\
\hline $\mathrm{S}$ & $\begin{array}{c}5.9 \\
(3.1-8.1)\end{array}$ & $\begin{array}{c}15.3 \\
(3.0-30.0)\end{array}$ & $\begin{array}{c}26.2 \\
(10.0-44.0)\end{array}$ & $\begin{array}{c}3.8 \\
(1.2-7.4)\end{array}$ & $\begin{array}{c}0.7 \\
(0.2-1.7)\end{array}$ & $\begin{array}{c}2.8 \\
(0.9-9.6)\end{array}$ \\
\hline $\mathrm{D}$ & $\begin{array}{c}5.8 \\
(2.6-8.5)\end{array}$ & $\begin{array}{c}14.3 \\
(2.0-31.0)\end{array}$ & $\begin{array}{c}25.1 \\
(8.0-42.0)\end{array}$ & $\begin{array}{c}3.7 \\
(0.8-14.2)\end{array}$ & $\begin{array}{c}0.6 \\
(0.3-2.5)\end{array}$ & $\begin{array}{c}2.6 \\
(0.7-4.6)\end{array}$ \\
\hline $\mathrm{S}+\mathrm{D}$ & $\begin{array}{c}5.9 \\
(2.6-8.5)\end{array}$ & $\begin{array}{c}14.7 \\
(2.0-31.0)\end{array}$ & $\begin{array}{c}25.1 \\
(8.0-44.0)\end{array}$ & $\begin{array}{c}3.8 \\
(0.7-14.2)\end{array}$ & $\begin{array}{c}0.7 \\
(0.2-2.5)\end{array}$ & $\begin{array}{c}2.7 \\
(0.7-9.6)\end{array}$ \\
\hline
\end{tabular}

\section{Bacterial activity in diffusion chambers assays}

Salinity in diffusion chambers filled with water from the brackish water zone was 9 to 23 psu lower than in chambers filled with marine water (Fig. 4). The time course of the salinity values indicated that the permeation through the membranes allowed a rapid ( 2 to $3 \mathrm{~h}$ ) equilibrium in the concentration of dissolved materials between the chamber and the bath compartments (Fig. 4).

At time zero of the incubations, the total bacterial number was 1.3 to 2.6 times higher in the brackish water. The active bacterial number, determined by microautoradiography (February and June 1998) was 2.3 to 2.8 times higher in the brackish water, but when determined through CTC reduction (November 1999) it was 5.6 times higher in the brackish water zone. The percentage of active bacterial cells varied from 14.2 to $32.1 \%$ as determined by microautoradiography (February and June 1998), and between 2.9 and $6.4 \%$ when determined by the CTC reduction method (November 1999). Leucine incorporation was also higher in the brackish water (2.0 to 10.8 times).

The bacterial community responded quickly to exposure to the contrasting water. Changes in leucine incorporation and in the proportion of active bacteria were detectable after $2 \mathrm{~h}$ of exposure to contrasting conditions (Figs 5 \& 6). When the marine bacterial community was exposed to the brackish water environment, the fraction of active bacteria and leucine incorporation increased. The opposite was observed when the brackish water community was exposed to marine water.
The amplitude of positive and negative effects was different between variables and between experiments. The variation in the fraction of active bacteria during exposure was lower than that observed in leucine incorporation. The fraction of active bacteria and bacterial productivity in the marine zone increased 20 to 60 and 50 to $220 \%$, respectively, in relation to the control when exposed to brackish water conditions. The fraction of active bacteria and leucine incorporation in the brackish water decreased 20 and 50 to $80 \%$, respectively, after 2 to $6 \mathrm{~h}$ of incubation in marine water (Figs 5 \& 6).

The results of the reversion assays performed in June 1998 indicated, as mentioned before, that exposure of the bacterial community for $2 \mathrm{~h}$ to the contrasting water was sufficient to activate marine bacteria or to inactivate brackish water bacteria (Fig. 7). The fraction of active bacteria increased by $25 \%$ in the marine community and decreased by $22 \%$ in the brackish water community after $6 \mathrm{~h}$ of exposure. Leucine incorporation increased by $30 \%$ in the marine zone and decreased by $56 \%$ in the brackish water zone. The positive response of marine bacteria to brackish water was reversible: when marine bacteria returned to marine water the fraction of active bacteria and leucine incorporation decreased, reaching values similar to those of the control. However, the negative effect of marine water on the brackish water community was irreversible. After $2 \mathrm{~h}$, when the brackish water bacterial community returned to brackish water, the fraction of active bacteria and leucine incorporation remained stable during the $4 \mathrm{~h}$ of incubation. 

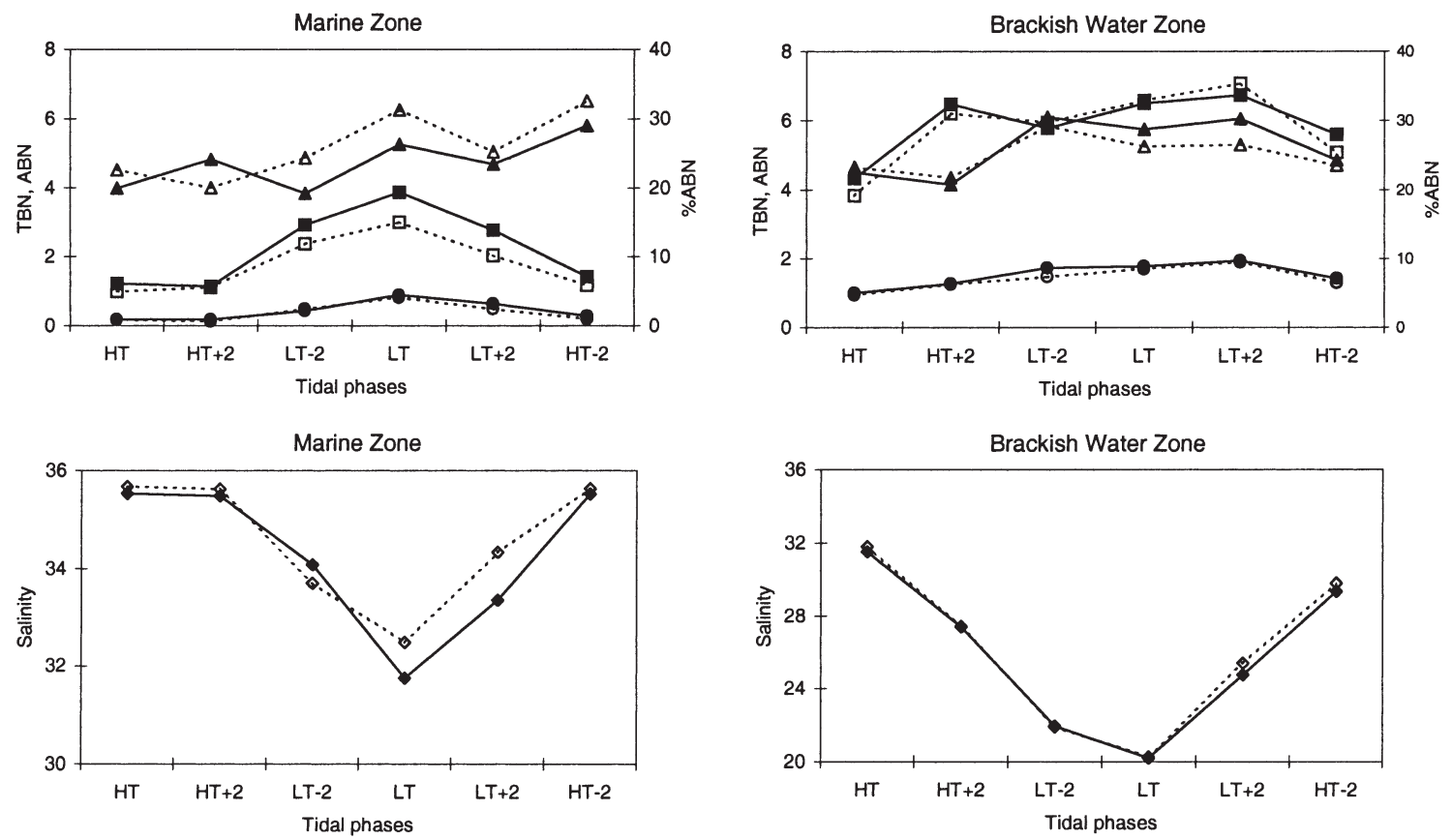

Fig. 2. Bacterial abundance in the marine and brackish water zones of the Ria de Aveiro. Determinations at surface $(0.2 \mathrm{~m}$ below surface) and deep ( $0.5 \mathrm{~m}$ above sediment floor) water, at high tide (HT) and low tide (LT) and at intervals of $2 \mathrm{~h}$ as indicated. The values shown for each tidal phase were calculated as the average of 6 (marine zone) and 4 (brackish water zone) determinations at different sampling dates of the warm season. Total bacterial number $\left(\times 10^{9} \mathrm{l}^{-1}\right)$ at surface water (TBN $\longrightarrow$ - - and deep water (TBN --- $\left.\square^{---}\right)$; active bacterial number determined by microautoradiography $\left(\times 10^{8} \mathrm{l}^{-1}\right)$ at surface water (ABN $\left.\longrightarrow-\right)$ and deep

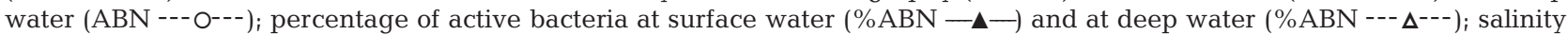
(psu) at surface water $(\longrightarrow)$; salinity (psu) at deep water $\left(---\diamond^{---}\right)$
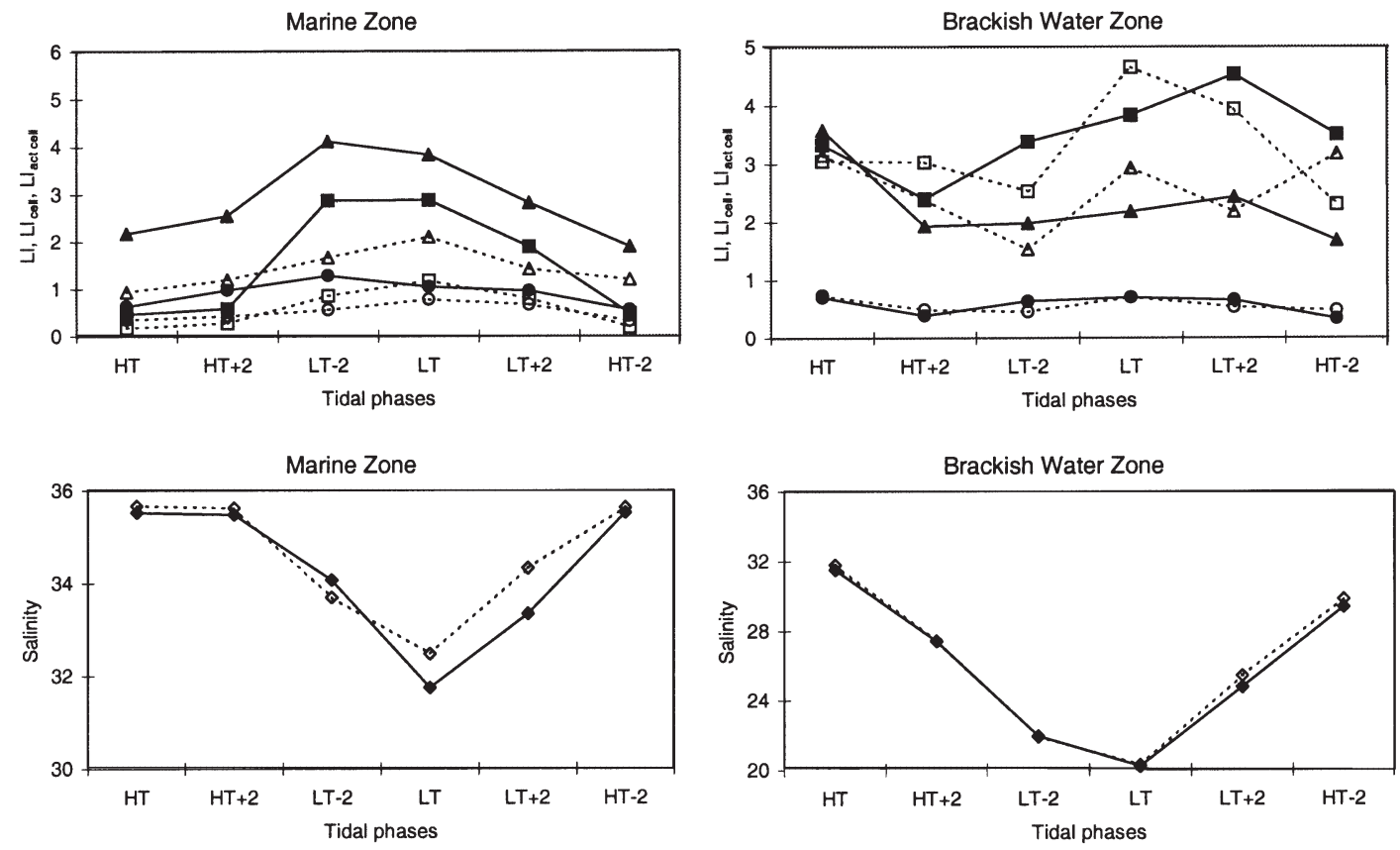

Fig. 3. Leucine incorporation in the marine and brackish water zones. Determinations as indicated in Fig. 2. Leucine incorporation $\left(\mu \mathrm{g} \mathrm{C}^{-1} \mathrm{~h}^{-1}\right)$ at surface water (LI - - ) and deep water (LI---- $\left.{ }^{----}\right)$; leucine incorporation per cell (fg C cell $\left.{ }^{-1} \mathrm{~h}^{-1}\right)$ at surface water $\left(\mathrm{LI}_{\text {cell }} \longrightarrow-\right.$ ) and deep water $\left(\mathrm{LI}_{\text {cell }^{--}}{ }^{-\mathrm{O}^{---}}\right)$; leucine incorporation per active cell determined by microautoradiography (fg $\mathrm{C}$ active cell $\left.{ }^{-1} \mathrm{~h}^{-1}\right)$ at surface water $\left(\mathrm{LI}_{\text {act cell }}-\boldsymbol{\Lambda} \longrightarrow\right.$ ) and at deep water $\left(\mathrm{LI}_{\text {act cell }}{ }^{---\Delta^{---}}\right)$; salinity (psu) at surface water $(\longrightarrow-)$; salinity (psu) at deep water $\left(---\diamond^{---}\right)$ 


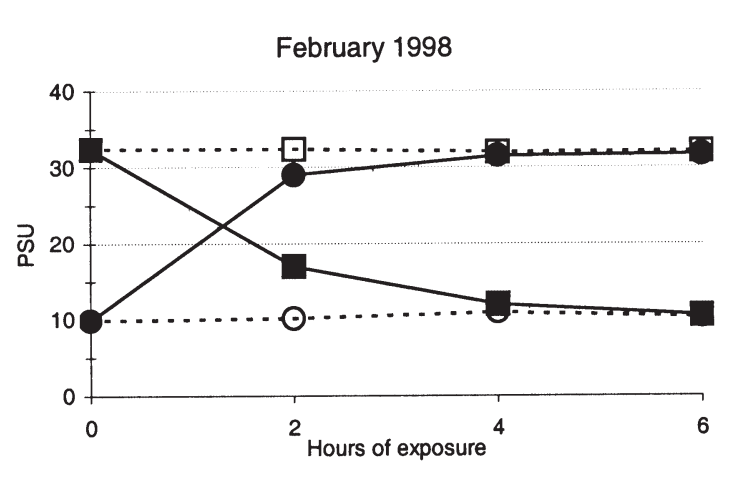

June 1998

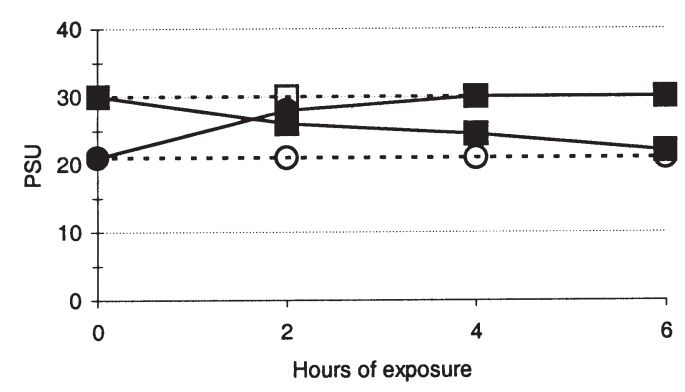

November 1999

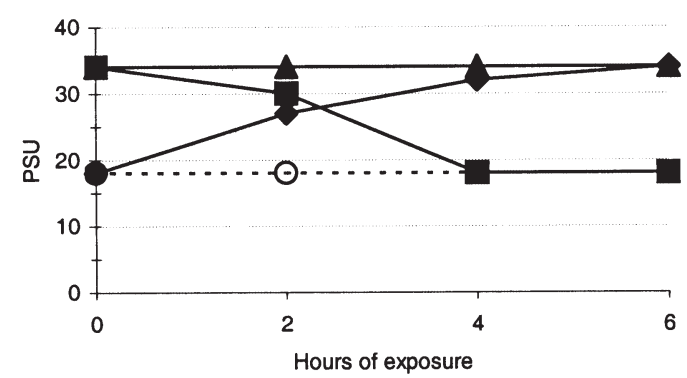

The positive response of marine bacteria to brackish water conditions was higher when the salinity of the brackish water was artificially increased to $34 \mathrm{psu}$ (Fig. 8). After $6 \mathrm{~h}$, the fraction of active bacteria and the
Fig. 4. Salinity evolution within the diffusion chambers when exposed during $6 \mathrm{~h}$ to water of the contrasting quality. Surface water samples were collected $2 \mathrm{~h}$ before high tide in the marine zone and $2 \mathrm{~h}$ before low tide in the brackish water zone. --- $\square---$ marine water chamber in marine water bath and similarly, - - marine water in brackish water, --- O--brackish water in brackish water, - - brackish water in marine water, - $\boldsymbol{\Delta}$ - marine water in brackish water increased to 34 psu, --- -- brackish water in brackish water increased to $34 \mathrm{psu}$

rate of leucine incorporation were approximately $50 \%$ higher than that observed in the 18 psu natural salinity of the parallel experiment. Brackish water bacteria, however, responded negatively to the increase in salinity. After $2 \mathrm{~h}$ of incubation, the fraction of active bacteria and the rate of leucine incorporation were, respectively, 13 and $23 \%$ lower than those registered in natural salinity.

\section{Bacterial activity after supplement amendment}

The active bacterial number (determined by the CTC reduction method) did not increase in marine and brackish water communities after the addition of different combinations of inorganic and organic substrates (Tables $3 \& 4$ ). The initial fraction of active bacteria determined with this technique was very small in both zones (average $5.0 \%$ ) and did not change significantly after substrate additions. The fraction of active bacteria determined in these assays by the CTC technique was much lower than that obtained by microautoradiography. Comparative studies had already shown that the CTC reduction technique gave a lower percentage of active bacteria than given by the microautoradiography technique (54\%, on average; data not shown). It is important to note, in disagreement with other authors (Choi et al. 1999), that it was not possible to detect activity effects by yeast extract, TSB (Tryptic Soy Broth) medium, peptone and triptone, as these substrates formed fluorescent precipitates after CTC addition, which might be con-

Table 3. Fraction of active cells after exposure to various combinations of supplements during different intervals of time. Marine water was collected between March 1998 and November 1999. See Table 1 for composition of supplements. ND: not determined

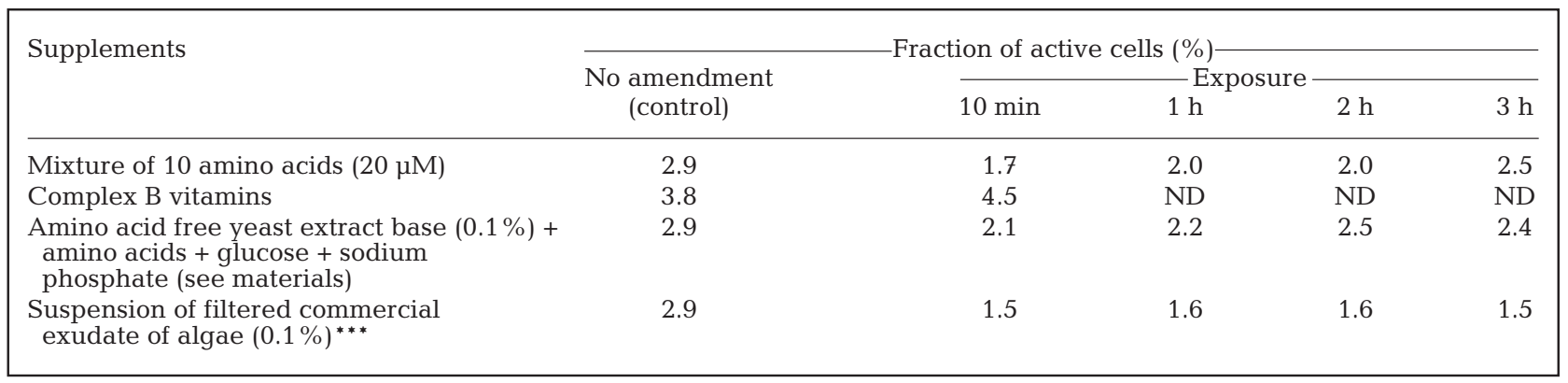



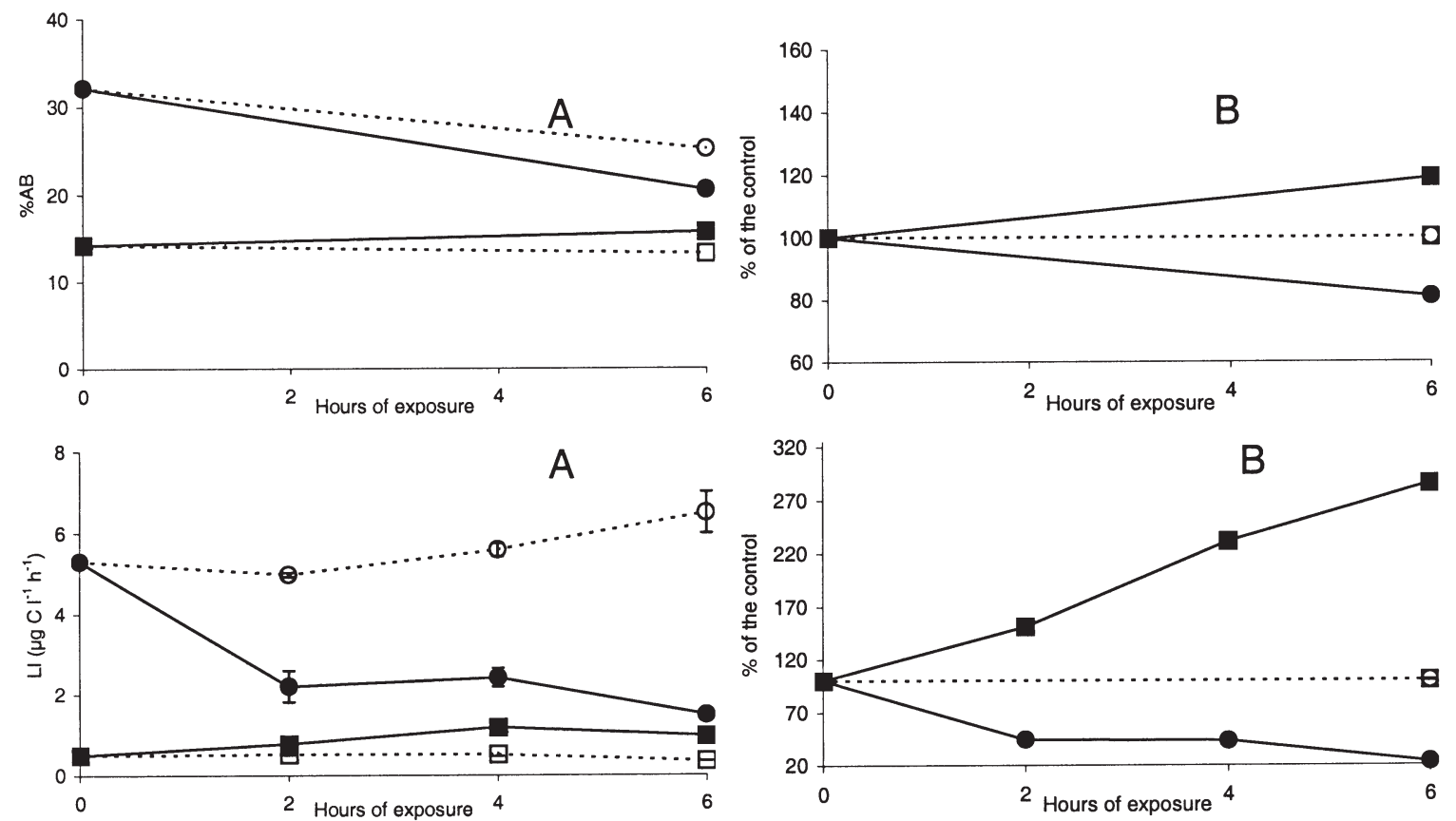

Fig. 5. (A) Variation in the fraction of active bacteria (\%AB) and in leucine incorporation (LI) during $6 \mathrm{~h}$ of exposure of bacterial communities to contrasting water. (B) Percentage of variation in relation to the control of \% AB and LI during the $6 \mathrm{~h}$ of exposure. February 1998. --- $\square---$ marine water chamber in marine water bath and, similarly, - - marine water in brackish water, --- --- brackish water in brackish water, - —- brackish water in marine water
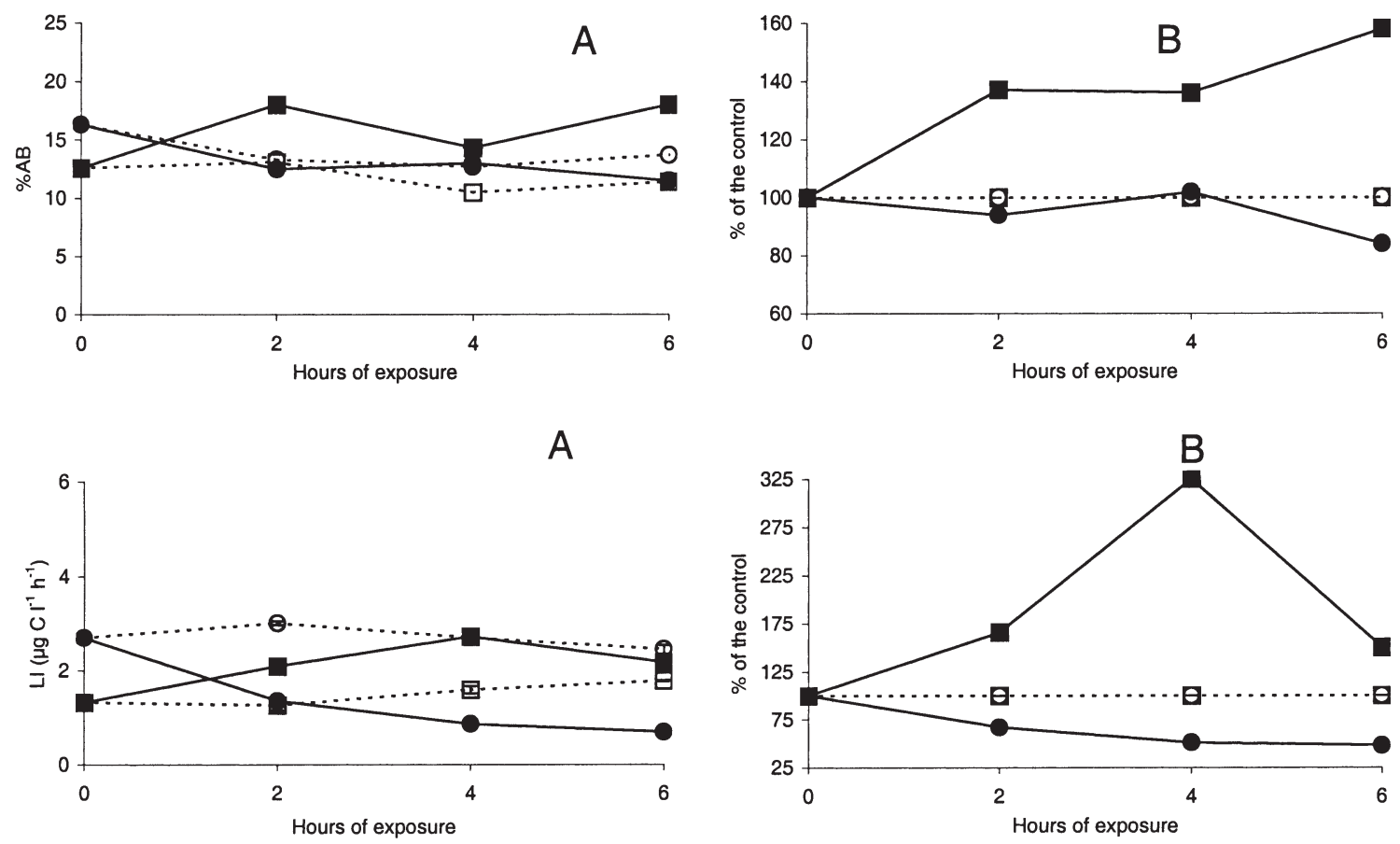

Fig. 6. (A) Variation in the fraction of active bacteria (\%AB) and in leucine incorporation (LI) during $6 \mathrm{~h}$ of exposure of bacterial communities to contrasting water. (B) Percentage of variation in relation to the control of \% AB and LI during the $6 \mathrm{~h}$ of exposure. June 1998. --- $\square^{---}$marine water chamber in marine water bath and, similarly — - marine water in brackish water, --- O--- brackish water in brackish water, _- - brackish water in marine water 

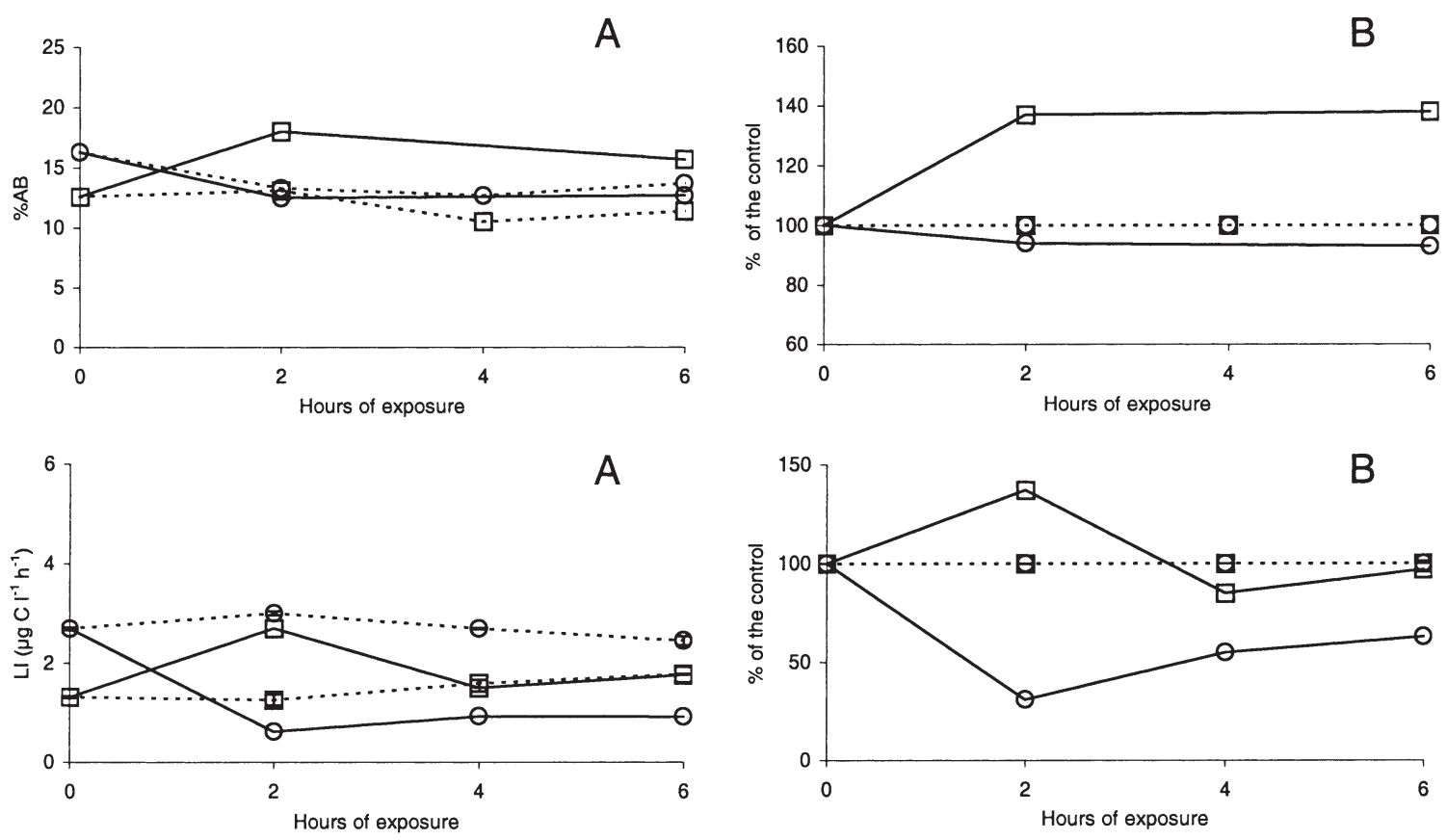

Fig. 7. (A) Variation in the fraction of active bacteria (\% AB) and in leucine incorporation (LI) during $2 \mathrm{~h}$ of exposure of bacterial communities to the contrasting water followed by reversion to water of their natural environment for an extra $4 \mathrm{~h}$. (B) Percentage of variation in relation to the control of \% AB and LI during the $6 \mathrm{~h}$ of exposure. June 1998. - $\square-$ marine water in brackish water and reversion to marine water, - $\mathrm{O}$ - brackish water in marine water and reversion to brackish water, ---- $\square---$ marine water in marine water, --- - --- brackish water in brackish water
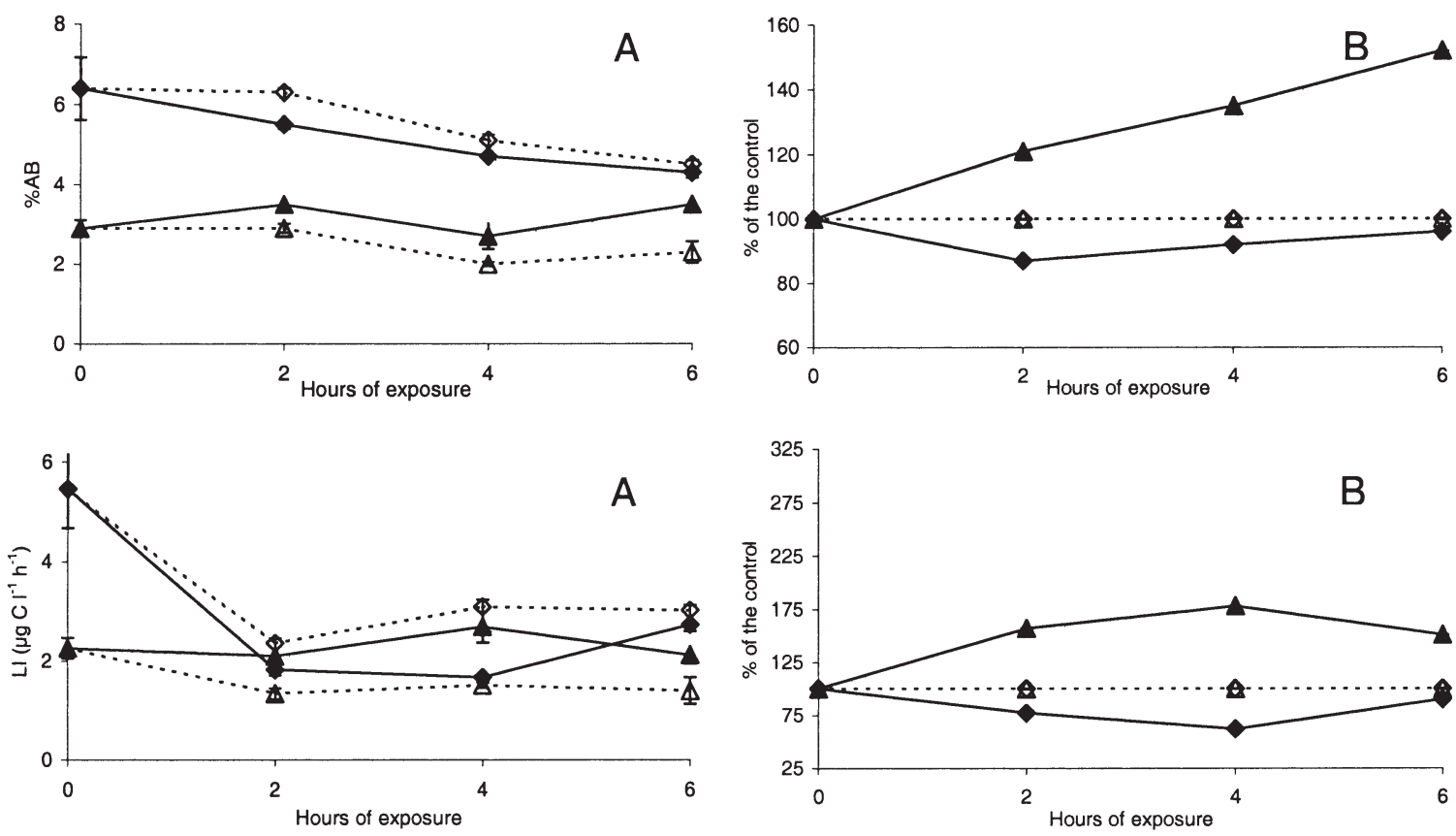

Fig. 8. (A) Variation in the fraction of active bacteria (\% AB) and in leucine incorporation (LI) during $6 \mathrm{~h}$ of exposure of marine and brackish water bacterial communities to brackish water with natural salinity (18 psu) or with increased salinity (34 psu). (B) Percentage of variation in relation to the control of \% AB and LI during the $6 \mathrm{~h}$ of exposure. November 1999. --- $\Delta^{----}$marine water in brackish water with natural salinity (18 psu), --- - --- brackish water in brackish water with natural salinity $(18$ psu), - $-\mathbf{\Delta}-$ marine water in brackish water with increased salinity (34 psu), $\longrightarrow$ - brackish water in brackish water with increased salinity (34 psu) 
Table 4. Fraction of active cells after exposure to various combinations of supplements. Brackish water was collected between January 1988 and January 1999. ${ }^{*}$ See Table 3 for amino acid composition. ${ }^{\text {TFiltered }}(0.2 \mu \mathrm{m}$ pore size membranes) extract of diatoms (Amphora coffeaeformis, Melosira nummuloides, Bacillaria paxillifera, Coscinodiscus granii, Navicula directa, Cymbella sp.) suspended in their culture medium

\begin{tabular}{|c|c|c|}
\hline $\begin{array}{l}\text { Substrate } \\
\text { (conc.) }\end{array}$ & $\begin{array}{l}\text { Non-amended } \\
\text { control (\% AB) }\end{array}$ & $\begin{array}{l}\text { Amended (increase } \\
\text { or decrease) }\end{array}$ \\
\hline Glucose $(0.1 \%)$ & 9.9 & +1.1 \\
\hline Sodium phosphate $(0.05)$ & 9.9 & +0.2 \\
\hline Sodium phosphate $(0.1 \%)$ & 4.3 & -0.1 \\
\hline Fructose $(0.1 \%)$ & 5.7 & +2.6 \\
\hline Sacarose $(0.1 \%)$ & 3.9 & +0.1 \\
\hline Mixture of 10 amino acids $(20 \mu \mathrm{M})^{*}$ & 9.9 & +0.2 \\
\hline $\begin{array}{l}\text { Amino acid and nitrogen } \\
\text { free yeast extract base }(0.1 \%)\end{array}$ & 3.8 & 0 \\
\hline $\begin{array}{l}\text { Yeast extract base without } \\
\text { amino acids }(0.1 \%)\end{array}$ & 3.8 & 0 \\
\hline $\begin{array}{l}\text { Amino acid free yeast extract base }(0.1 \%) \\
\text { amino acids }(20 \mu \mathrm{M})\end{array}$ & +3.8 & 0 \\
\hline $\begin{array}{l}\text { Amino acid free yeast extract base }(0.1 \%) \\
\text { amino acids }(20 \mu \mathrm{M})+ \\
\text { complex B vitamins }\end{array}$ & +3.8 & 0 \\
\hline $\begin{array}{l}\text { Exudate of diatoms isolated } \\
\text { in the Ria de Aveiro }(0.1 \%)^{* *}\end{array}$ & 4.3 & +3.2 \\
\hline Diatoms growth medium (f/2) $(0.1 \%)$ & 4.3 & +0.4 \\
\hline
\end{tabular}

cell (19\% increase in brackish water) would be explained by the observed nutrient gradient. This hypothesis of conservative transport is weakened by the relatively long residence time of freshwater in the mid-estuary (10 to $97 \mathrm{~d}$ ) and in the outer estuary (1 to 45 d) (Silva 1994).

The long exposure of the bacterial community during transport to a less favourable environment than upstream may interfere with the spatial patterns of abundance and activity. When residence time is long, distinct bacterial assemblages may occur in different zones of the estuary.

To clarify these 2 interpretations and to evaluate the importance of the salinity gradient in the eventual differentiation of estuarine bacterial communities, we looked for experimental evidence in diffusion chambers experiments. When the marine and brackish water communities were exposed to reciprocally exchanged water they responded promptly $(<6 \mathrm{~h})$ fused with bacteria. For this reason the results concerning these substrates could not be considered.

\section{DISCUSSION}

Previous work in this estuary (Cunha et al. 2000) has shown that bacterioplankton abundance and activity (leucine incorporation, ectoenzymatic activities and glucose turnover) follow a curvilinear longitudinal profile. These variables reach maximal values generally in mid-estuary (20 to $30 \mathrm{psu}$ ) in response to a set of favourable conditions including organic matter and nutrient availability. For this reason, it may be expected that in this estuary section not only would the number of active bacteria be greater than in any other region of the salinity gradient but also their proportion in the total bacterial community would increase. The percentages of active bacteria in marine and brackish water were, however, very close (average $27.9 \%$ in the marine zone and $25.1 \%$ in the brackish water zone) in similar sampling occasions although they varied within a considerable range ( 6 to $55 \%$ in the marine zone; 8 to $44 \%$ in brackish water). This variation was erratic, with no relation to tidal water circulation. The constancy in the fraction of the active bacteria may be interpreted as denoting the conservative transport of bacterial cells along the estuarine salinity gradient. The alteration in the average level of activity per active and inversely to the new environment. Leucine incorporation and the fraction of active bacteria increased in the marine community incubated in brackish water. On the contrary, the brackish water community challenged with marine water responded negatively, reducing leucine incorporation and the fraction of active bacteria. Again, this may be associated solely with the higher concentrations of organic carbon and nutrients in the microcosms exposed to brackish water. It is underlined that the decrease in salinity (from 32 to $16 \mathrm{psu}$, on average) did not preclude the positive response of the marine community to brackish water, although the artificial increase of the brackish water salinity to $34 \mathrm{psu}$ produced a more intense reaction in the marine bacteria.

The attempted discrimination between several simple and complex substrates that may be more or less involved in the promotion of bacterial activity in the conditions of this estuary was not successful. The size of the active community was insensitive to $3 \mathrm{~h}$ exposure to any of the chosen substrates. These results, confronted with the positive reactions obtained with natural water in diffusion chambers, may indicate that a combination of factors may be required to induce bacterial activation. The awakening cell activity after experimental stimulation may not, however, be detectable through CTC-reduction due to the toxicity of the chemical (Davey \& Kell 1996, Ullrich et al. 1996, Karner \& Fuhrman 1997). 
The reversion experiments in microcosms produced results that were more informative. They showed a distinct contrast between brackish water and marine bacteria. After the prompt and positive response during the initial $2 \mathrm{~h}$ incubation in nutrient-rich brackish water, the marine bacteria, when transferred back to marine water, reverted rapidly to the activity profiles shown by the control. In similar experiments with brackish water bacteria exposed to marine water and then returned to brackish water, the response was negative, rapid and irreversible in the $6 \mathrm{~h}$ course of the experiment. This suggests that the high percentage of non-active bacterial cells observed in this estuary may result, at least partially, from the impact of the flooding current on brackish water bacteria. In fact, at HT, this current brings into the lagoon enough water to increase salinity above 28 psu in $99 \%$ of the total water volume (compared with $35 \%$ in LT) (Silva 1994). Alternatively, the irreversible negative responses of brackish water bacteria to marine water in contrast with the positive and reversible reactions of marine bacteria to brackish water suggest the presence of distinct bacterial assemblages adapted to the environmental conditions prevailing in different sections of the estuary, as was found in other estuaries through genetic approaches by denaturing gradient gel electrophoresis of 16S rDNA fragments and by low molecular weight RNA analysis (Bidle \& Fletcher 1995, Murray et al. 1996). The bacterial reactivity speaks against the hypothesis of conservative transport in this estuary.

\section{CONCLUSION}

Most of the bacterioplankton from this estuary (ca $70 \%$ ) was inactive, as revealed by microautoradiography. Amendment assays with different nutrients could not stimulate hypothetical inactive cells, indicating that this fraction is composed mostly of dead cells. The CTC-reduction technique used in these assays may not, however, be the best method to detect incipient activity. The small size of the fraction of active cells in the mid-estuary can result from the negative and mostly irreversible impact of flooding water on brackish water bacteria as observed experimentally.

The hypothesis of conservative transport of the upper and mid-estuary bacteria, suggested by field data on bacterial abundance and activity in Ria de Aveiro, is not sustained by the experimental results obtained in diffusion chambers. These results suggest the presence of 2 different communities: (1) a marine zone community, limited by a short supply of nutrients, reacting positively to nutrient-rich brackish water (down to $16 \mathrm{psu}$ ) and to high salinities (ca $34 \mathrm{psu}$ ); and (2) a brackish water community, growing in rich water, that reacts negatively and irreversibly to salinities above 25 psu. Salinity and nutrient availability seem to control the activity of these 2 communities generating an apparently conservative longitudinal continuum.

\section{LITERATURE CITED}

Almeida MA, Cunha MA, Alcântara F (in press) Factors influencing bacterial production in a shallow estuarine system. Microb Ecol

Barrosa JA (1985) Breve caracterização da Ria de Aveiro. Jornadas da Ria de Aveiro. Volume II. Recursos da Ria de Aveiro. Edição da Câmara Municipal de Aveiro, Aveiro, p $1-9$

Bidle KD, Fletcher M (1995) Comparison of free-living and particle associated bacterial communities in the Chesapeake Bay by stable low-molecular-weight RNA analysis. Appl Environ Microbiol 61:944-952

Bird DF, Kalff J (1993) Protozoan grazing and size-activity structure in limnetic bacterial communities. Can J Fish Aquat Sci 50:370-380

Bligh SP, Bentley TL, Lefevre D, Robinson C, Rodrigues R, Rowlands J, Williams P (1995) Phasing autotrophic and heterotrophic plankton metabolism in a temperate coastal ecosystem. Mar Ecol Prog Ser 128:61-75

Bordalo AA, Pinto MM, Carvalho LM (1998) Dinâmica sazonal e espacial de variáveis abióticas e bióticas no estuário do Rio Douro. Actas do $1^{\circ}$ Simpósio Interdisciplinar sobre processos estuarinos, Universidade do Algarve, Faro, p 47-48

Button DK, Robertson BR (1993) Use of high-resolution flow cytometry to determine the activity and distribution of aquatic bacteria. In: Kemp PF, Sherr BF, Sherr EB, Cole JJ (eds) Handbook of methods in aquatic microbial ecology. Lewis Publishers, New York, p 163-173

Carman K (1993) Microautoradiographic detection of microbial activity. In: Kemp PF, Sherr BF, Sherr EB, Cole JJ (eds) Handbook of methods in aquatic microbial ecology. Lewis Publishers, New York, p 397-404

Choi JW, Sherr BF, Sherr EB (1999) Dead or alive? A large fraction of ETS-inactive marine bacterioplankton cells, as assessed by reduction of CTC, can become ETS-active with incubation and substrate addition. Aquat Microb Ecol 18:105-115

Cole JJ, Caraco NF (1993) The pelagic food web of oligotrophic lakes. In: Ford TE (ed) Aquatic microbiology. An ecological approach. Blackwell Scientific Publications, Boston, p 101-111

Cunha MA, Almeida MA, Alcântara F (1999) Compartments of oxygen consumption in a tidal mesotrophic estuary (Ria de Aveiro, Portugal). Acta Oecol 20:227-235

Cunha MA, Almeida MA, Alcântara F (2000) Patterns of variation of ectoenzymatic and heterotrophic bacterial activities along a salinity gradient in a shallow tidal estuarine. Mar Ecol Prog Ser 204:1-12

Cunha MA, Almeida MA, Alcântara F (in press) Short-time responses of the natural planktonic bacterial community of the changing water properties in an estuarine environment: ectoenzymatic activity, glucose incorporation and biomass production. Microb Ecol

Davey HM, Kell DB (1996) Flow cytometry and cell sorting of heterogeneous microbial populations: the importance of single-cell analysis. Microbiol Rev 60:641-696

del Giorgio PA, Scarborough G (1995) Increase in the proportion of metabolically active bacteria along gradients of 
enrichment in freshwater and marine plankton: implications for estimates of bacterial growth and production rates. J Plankton Res 17:1905-1924

del Giorgio PA, Gasol JM, Vaqué D, Mura F, Agustí S, Duarte CM (1996) Bacterioplankton community structure: protists control net production and the proportion of active bacteria in a coastal marine community. Limnol Oceanogr 41: 1169-1179

Gasol JM, del Giorgio PA, Massana R, Duarte CM (1995) Active versus inactive bacteria: size-dependence in a coastal marine plankton community. Mar Ecol Prog Ser 128:91-97

Gonzalez JM, Sherr EB, Sherr BF (1990) Size selective grazing on bacteria by natural assemblage of estuarine flagellates and ciliates. Appl Environ Microbiol 40:156-160

Goosen NK, van Rijswijk P, Kromkamp J, Peene J (1997) Regulation of annual variation in heterotrophic bacterial production in the Schelde estuary (SW Netherlands). Aquat Microb Ecol 12:223-232

Hobbie JE, Daley R, Jasper S (1977) Use of Nuclepore filters for counting bacteria by fluorescence microscopy. Appl Environ Microbiol 33:1225-1228

Karner M, Fuhrman JA (1997) Determination of active marine bacterioplankton: a comparison of universal 16s rRNA probes, autoradiography, and nucleoid staining. Appl Environ Microbiol 63:1208-1213

Murray AE, Hollibaugh JT, Orrego C (1996) Phylogenetic composition of bacterioplankton from two California estuaries compared by denaturing gradient gel electrophoresis of $16 \mathrm{~S}$ rDNA fragments. Appl Environ Microbiol 62: 2676-2680

Palumbo AV, Fergunson RL (1978) Distribution of suspended bacteria in the Newport River estuary, North Carolina. Estuar Coast Mar Sci 7:521-529

Parsons TR, Maita Y, Lalli CM (1989) A manual of chemical and biological methods for seawater analysis. Pergamon Press, Oxford

Pereira G, Alcântara F (1993) Culturability of Escherichia coli and Stretrococcus faecalis in batch culture and in situ in estuarine water (Portugal). Water Res 27:1351-1360

Proctor LM, Fuhrman JA (1990) Viral mortality of marine cyanobacteria and bacteria. Nature 343:60-62

Quinn JP (1984) The modification and evaluation of some

Editorial responsibility: James Hollibaugh,

Athens, Georgia, USA cytochemical techniques for the enumeration of metabolically active heterotrophic bacteria in the aquatic environment. J Appl Bacteriol 57:51-57

Riegsbee W, Simpson L, Oliver J (1996) Detection of the viable but nonculturable state in Escherichia coli O157:h7. J Food Saf 16:255-262

Rodriguez GG, Phipps D, Ishiguro K, Ridgway HF (1992) Use a fluorescent redox probe for direct visualisation of actively respiring bacteria. Appl Environ Microbiol 58:1801-1810

Sherr BF, Sherr EB, McDaniel J (1992) Effects of protistan grazing on the frequency of dividing cells in bacterioplankton. Appl Environ Microbiol 58:2381-2385

Sherr BF, del Giorgio P, Sherr EB (1999) Estimating abundance and single-cell characteristics of respiring bacteria via the redox dye CTC. Aquatic Microb Ecol 18:117-131

Shiah F, Ducklow HW (1994) Temperature and substrate regulation of bacterial abundance, production, and specific growth rate in Chesapeake Bay. Limnol Oceanogr 39: $1243-1258$

Silva JJ (1994) Circulação de Água na Ria de Aveiro: Contribuição para o Estudo da Qualidade da Água. PhD thesis, Universidade de Aveiro

Simon M, Azam F (1989) Protein content and protein synthesis rates of planktonic bacteria. Mar Ecol Prog Ser 51: 201-213

Tabor PS, Neihof RA (1984) Direct determination of activities for microorganisms of Chesapeake Bay populations. Appl Environ Microbiol 48:1012-1019

Ullrich S, Karrasch B, Hoppe H, Jeskulke K, Mehrens M (1996) Toxic effects on bacterial metabolism of the redox dye 5-cyano-2,3-ditolyl tetrazolium chloride. Appl Environ Microbiol 62:4587-4593

Wright RT, Coffin RB (1983) Planktonic bacteria in estuaries and coastal waters of northern Massachusetts: spatial and temporal distribution. Mar Ecol Prog Ser 11:205-216

Wright RT, Coffin RC (1984) Factors affecting bacterioplankton density and productivity in salt marsh estuaries. In: Klug MJ, Reddy CA (eds) Current perspectives in microbial ecology. American Society for Microbiology, Washington, $\mathrm{p}$ 485-494

Zweifel U, Hagstrom A (1995) Total counts of marine bacteria include a large fraction of non-nucleoid-containing bacteria (ghosts). Appl Environ Microbiol 61:2180-2185

Submitted: May 25, 2000; Accepted: July 4, 2001

Proofs received from author(s): August 21, 2001 